\title{
In-Silico Identification of the Best Compound Against Leishmania infantum: High Throughput Screening of All FDA Approved Drugs
}

\author{
Leishmania infantum'a Karşı En İyi Bileşimin Silico Olarak \\ Tanımlanmasl: Tüm FDA Onaylı İlaçların Yüksek Verimli Tarama
}

\author{
(1) Jasem Saki ${ }^{1}$, (1) Farnoush Shadnoush ${ }^{1}$, (1) Reza Arjmand ${ }^{2}$, (1) Fakher Rahim ${ }^{3}$ \\ ${ }^{1}$ Cellular and Molecular Research Center, Ahvaz Jundishapur University of Medical Sciences, Ahvaz, Iran \\ ${ }^{2}$ Department of Medical parasitology, School of Medicine, Ahvaz Jundishapur University of Medical Sciences, \\ Ahvaz, Iran \\ ${ }^{3}$ Thalassemia and Hemoglobinopathies Research Center, Health research institute, Jundishapur University of \\ Medical Sciences, Ahvaz, Iran
}

Cite this article as: Saki J, Shadnoush F, Arjmand R. Rahim F. In-Silico Identification of the Best Compound Against Leishmania infantum: High Throughput Screening of All FDA Approved Drugs. Turkiye Parazitol Derg 2019;43(4):158-64.

\begin{abstract}
Objective: Current in-silico research was designed and administered for the screening of 20000 Food and Drug Administrationapproved drug compounds with the goal of finding promising drugs against lipophosphoglycan (LPG) and $\gamma$-glutamylcysteine synthetase ( $\gamma$-GCS) of Leishmania infantum.

Methods: After the protein sequence of both targets was taken, the 3D structures of protein of interest were predicted and validated. Molecular docking was done among the two putative targets (LPG and $\gamma$-GCS) and approved compounds were selected using AutoDock 4.2 program to predict ligand-receptor interactions.

Results: After docking experiment was done on 20000 drug compounds, a total number of seven ligands, two for $\gamma$-GCS receptor and five for LPG receptor, were assigned as novel, potent anti-leishmanial drugs based on their binding affinity and energy. Of those, five ligands possessed cytotoxic and anti-cancer characteristics and showed good binding capacity to LPG receptor with $\Delta_{\text {Gbinding }}$ up to $8.5 \mathrm{kcal} / \mathrm{mol}$ more negative; while two compounds showed good binding capacity to glutamyl receptor with $\Delta_{\text {Gbinding }}$ up to $7.8 \mathrm{kcal} / \mathrm{mol}$ more negative.

Conclusion: The latest software-based methods are powerful tools for scanning and predicting new peptide templates specific to biological targets in organisms for new drug discovery. However, the use of in vitro and in vivo techniques is a requirement for better evaluation of the potential of projected ligands with the help of in-silico approaches, identifying molecular mechanism of action of the more active compounds is possible. This can help in defining the most likely molecular target, so that the subsequent optimization using in vitro and in vivo techniques can be undertaken.

Keywords: In-silico, lipophosphoglycan, $\gamma$-glutamylcysteine synthetase, molecular docking, cytotoxic and anti-cancer activity
\end{abstract}

öz

Amaç: Mevcut in-silico araştırması, Leishmania infantum lipofosfoglikan (LPG) ve $\gamma$-glutamilsistein sentetazına ( $\gamma$-GCS) karşı umut verici ilaçlar bulmak amacıyla 20000 Gıda ve İlaç İdaresi onaylı ilaç bileşiklerinin taranması için tasarlandı ve uygulandı. Yöntemler: Her iki hedefin protein sekansı alındıktan sonra, 3D yapıları tahmin edildi ve doğrulandı. Moleküler yerleştirme iki varsayılan hedef (LPG ve $\gamma$-GCS) arasında yapıldı ve ligand-reseptör etkileşimlerini tahmin etmek için AutoDock 4.2 programı kullanılarak onaylanmış bileşikler seçildi.

Bulgular: Yirmi bin ilaç bileşiği üzerinde deney yapıldıktan sonra, $\gamma$-GCS reseptörü için iki ve LPG reseptörü için beş olmak üzere toplam yedi ligand, bağlanma afiniteleri ve enerjilerine göre yeni, güçlü anti-leishmanial ilaçlar olarak belirlenmiştir. Bunlardan 5 ligand 8,5 kcal/mol'e kadar daha negatif $\Delta_{\text {Gbinding }}$ ile LPG reseptörüne iyi bağlanma kapasitesi gösteren sitotoksik ve anti-kanser özelliklere sahipti. Bunlardan 2 ligand, 7,8 kcal/mol'e kadar daha negatif $\Delta_{\text {Gbinding }}$ ile glutamil reseptörüne iyi bir bağlanma kapasitesi gösterdi.

Sonuç: En yeni yazılım tabanlı yöntemler, yeni ilaç keşfi için organizmalarda biyolojik hedeflere özgü yeni peptid şablonlarını taramak ve tahmin etmek için güçlü araçlardır. Bununla birlikte, in vitro ve in vivo tekniklerin kullanımı, öngörülen ligandların 
potansiyelinin daha iyi değerlendirilmesi için bir gerekliliktir. İn-silico yaklaşımların yardımı ile daha aktif bileşiklerin moleküler düzeyde etki mekanizmasınının tanımlanması mümkün olmaktadır ve böylece en olası moleküler hedef belirlenebilmekte ve in vitro ve in vivo teknikleri kullanarak sonraki optimizasyon yapilabilmektedir.

Anahtar Kelimeler: In-siliko, lipofosfoglikan, $\gamma$-glutamilsistein sentetaz, moleküler yerleştirme, sitotoksik ve anti-kanser aktivitesi

\section{INTRODUCTION}

The protozoan parasites of Leishmania spp. are the causative agents of a neglected disease called leishmaniasis, being considered as a significant health concern in tropical and subtropical regions of the world (1). This infection usually disseminates via the bite of a female sand fly and renders different clinical manifestations from cutaneous ulcers to mostly pernicious visceral leishmaniasis (VL) (2). Approximately, one hundred nations have documented leishmaniasis infection with 350 million at-risk individuals residing in endemic territories. As a global perspective, 12 million people are infected and the incidence rates for VL is calculated to be 0.2-0.4 million cases annually (3). Over ninety percent of VL cases occur in six countries, including Brazil, India, Sudan, Bangladesh, South Sudan and Ethiopia (4). Multiple factors are involved in the incidence of leishmaniasis, comprising sandfly and reservoir control issues, increased traditional traveling, suppressed host immunity due to disease complications and some drugs, lack of efficacious immunoprophylaxis as well as drug resistance to traditional therapies $(5,6)$. It has been disclosed that currently administered anti-leishmanial drugs are costly and may possess toxicity and develop drug resistance; hence, it is an urgent need for the development of novel, safe and affordable drugs to combat leishmaniasis $(7,8)$. Approved drugs, especially those approved by Food and Drug Administration (FDA), have favorable or validated pharmacokinetic properties and toxicological profiles, and the repositioning of existing drugs for new indications can potentially avoid expensive costs associated with early-stage testing of the hit compounds (9). The fundamentals of drug discovery rely on the determination of a distinct protein and/or metabolic pathway specific to the pathogen (10). Bioinformatics is a computerbased interdisciplinary approach for various inter-molecular prediction purposes such as peptide-receptor interactions (11). Recognizing structure-activity associations using in-silico screening would efficiently lead us to identify specific drug targets for such neglected infections (12). The conventional drug discovery needs about 14 year and approximately 2.5 billion USD to approve and launch a new drug. To overcome time and cost obstacles to conventional drug discovery the process of assessing new indication for existing and approved drugs called drug repositioning (DR), has been introduced so far. Through taking advantage of drugs already in clinical use for other indications or drugs that have cleared early safety phases of trials, DR can reduce the time and cost of the drug discovery process. Several insilico approaches have been established to apply the DR, including omics-based and molecular docking based approaches.

Trypanothione is a crucial molecule in the initial confront with host macrophages, neutralizing their reactive oxidative species and redox potential maintenance $(13,14)$. During its biosynthesis, the enzyme $\gamma$-glutamylcysteine synthetase $(\gamma$-GCS) catalyses the first and rate-limiting phase and possess imperative action in parasite survival, rendering it as a considerable drug target $(15,16)$. In contrast to other trypanosomatid species, the glycocalyx of Leishmania parasites constitutes of phosphoglycosylated glycans anchors of glycosylphosphatidylinositol (GPI). One of the most outstanding glycoconjugates of the Leishmania surface membrane is lipophosphoglycan (LPG) (17). This molecule may be an appropriate drug target since it is a strong agonist of toll-like receptors, inhibits the activation of protein kinase $C$, harnesses complement system and damages phagolysosome maturation (18). In this experimental study, we aimed to investigate in-silico anti-leishmanial activity of 3358 FDA-approved compounds against above-mentioned drug targets of Leishmania infantum ( $L$. infantum) and compared to amphotericin B and glucantime.

\section{METHODS}

\section{Template Selection and Confirmation}

At first, the FASTA format of amino acids sequences of LPG (Uniprot ID: A4I4C9) and $\gamma$-GCS (Uniprot ID: A4HY37) for $L$. infantum were gathered from the UniProt Database (https://www. uniprot.org), and was used in BLAST analysis. Then, a program search protein databases using a protein query called BLASTP was run against the protein data bank to find a three-dimensional (3D) determined structure according to the best alignment scores. Subsequently, respective 3D structural models for both molecules were created using Swiss-Model online software (https://swissmodel.expasy.org), then validated by Protein Model Portal (https://www.proteinmodelportal.org), saves v5.0 (http://servicesn.mbi.ucla.edu/SAVES/), and Protein Structure Evaluation Suite \& Server (http://www.prosess.ca) web servers.

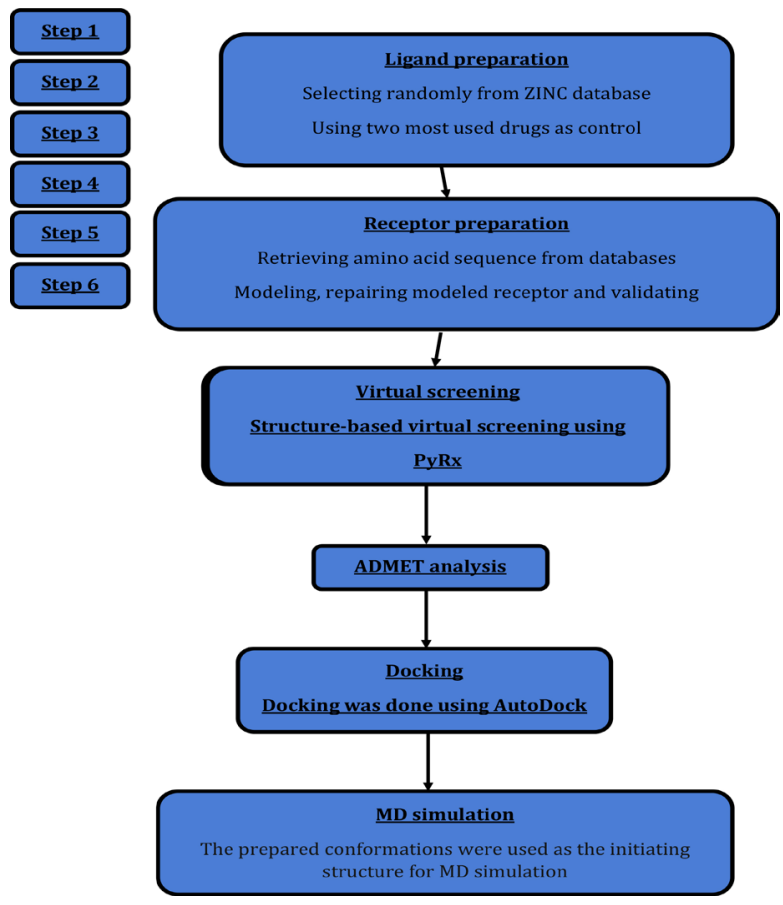

Figure 1. Schematic workflow for finding potential drug, ligands and receptors specific to the $L$. infantum receptor 
Finally, the selected protein was simulated using GROMACS 5.1.3 software (19) for $100 \mathrm{~ns}$ base on the ABMER03 force field. The flow diagram of finding potential drug, ligands and receptors specific to the L. infantum receptor has given in details (Figure 1 ).

\section{Ligands Library Preparation}

We used a method for template and FDA approved drug selection that we conducted and published previously (20). In brief, 20000 FDA approved drugs were randomly extracted from the ZINC database and tested against two selected receptors. For comparative study, the 3D structure of two known antileishmanial drugs from Drug Bank (https://www.drugbank.ca) and PubChem (https://pubchem.ncbi.nlm.nih.gov) databases were screened and appointed. Thus, a library of potential ligands was built. Also, two drug targets and FDA-approved drug compounds were prepared for molecular docking. Al ligands in the pdbqt format were retrieved using openbabel software and their energy was minimized by MMFF94 force field.

\section{Virtual Screening, and Control Setting}

In this study, we used structure-based virtual screening, a computational-aided technique used in the early-stage drug discovery campaign to search a chemical compound library for novel bioactive molecules against a drug target of interest (21). We used PyRx Software for virtual screening procedure. All 20000 selected FDA-approved drugs were docked using AutoDock Vina in PyRx 0.8 (22). These drugs with their chemical structure, physical properties, and clinical indications have been retrieved from various public databases, including PubChem , CheEMBL, DrugBank, and DrugCentral (23). Glucantime and amphotericin $B$ were used as control drugs in our experiment because they are standard treatment options for VL.

\section{Molecular Docking}

The AutoGrid section of AutoDock tools was employed to compute the grid maps of all LPG and $\gamma$-GCS molecules, taking into account large enough ones to include surface and active site. AutoDock 4.3 software was used for docking the chosen drug compounds into the active site of LPG and $\gamma$-GCS. The Lamarckian genetic algorithm-based AutoDock 4.2 was applied for ligand-receptor interactions. To increase docking efficiency, the total number of 63800 runs were performed for each drug target. Upon yielding docking values, cluster analysis was fulfilled in accordance with the root mean square $(0.5 \mathrm{~A})$.

The ligands were sketched and geometrically minimized using ACD Chemsketch (www.acdlabs.com) and Marvin Sketch (www. chemaxon.com), respectively. The ligands and proteins were then prepared using AutoDock Tools 1.5.6 (www.autodock.scripps. edu). The proteins were added with polar hydrogen and given by Kollman charge, whereas the ligands were given by Gasteiger charges. The grid was centered on each protein binding site and the docking was then performed using AutoDock Vina embedded in PyRx version 8.0 (www.autodock.scripps.edu). The hit of protein was selected based on the lowest mean of free energy of binding ( $D G_{\text {bind }}$ ), whereas a combination of a low $D G_{\text {bind }}$ and hydrogen bond interaction was considered to select the hit of the ligand. The selected docking pose was visualized using discovery studio 3.5 (www.accelyrs.com).

In the following, AutoDock Vina and AutoDock 4.2 were assigned to calculate free energy charge of binding and binding affinity. Below equation corresponds to computation of estimated free energy charge of binding: (6) estimated free energy charge of binding=torsional free energy of ligand + final inter - molecular energy

\section{Molecular Dynamic (MD) Simulation}

After preparing the template and ligands, the prepared conformations were used as the initiating structure for molecular dynamic (MD) simulation. The acquired conformation of $\mathrm{MD}$, as well as the docked ligands, were engaged in the MD simulation process. All MD simulations were done using the GROMACS 5.1 .3 software package and the AMBER03 force field, in a box with dimensions of $96 \times 95 \times 100 \AA$. The force field parameters were acquired from the antechamber module (22) of the Amber program, using the GAFF force field (23). Partial charges of the ligands were assigned using the AM1-BCC model (24), and an energy minimization method was performed. After energy minimization, a position restraint process was accomplished in association with NVT and NPT ensembles. Finally, the selected protein was simulated using GROMACS 5.1 .3 software (19) for $100 \mathrm{~ns}$ base on the ABMER03 force field.

\section{RESULTS}

In total, three and seven templates were predicted using Swissmodel for LPG and $\gamma$-GCS, respectively. The best model for LPG was the second model, whereas the best one for $\gamma$-GCS was the first template, with XP_001468657.1 vs XP_001464978.1 sequence identities, e-values of $1.18962 \mathrm{e}-124$ vs $2.26415 \mathrm{e}-140$ and final total model energies of $-12670.841 \mathrm{~kJ} / \mathrm{mol}$ vs $-12892.576 \mathrm{~kJ} / \mathrm{mol}$ (Figure 2A and 2B).

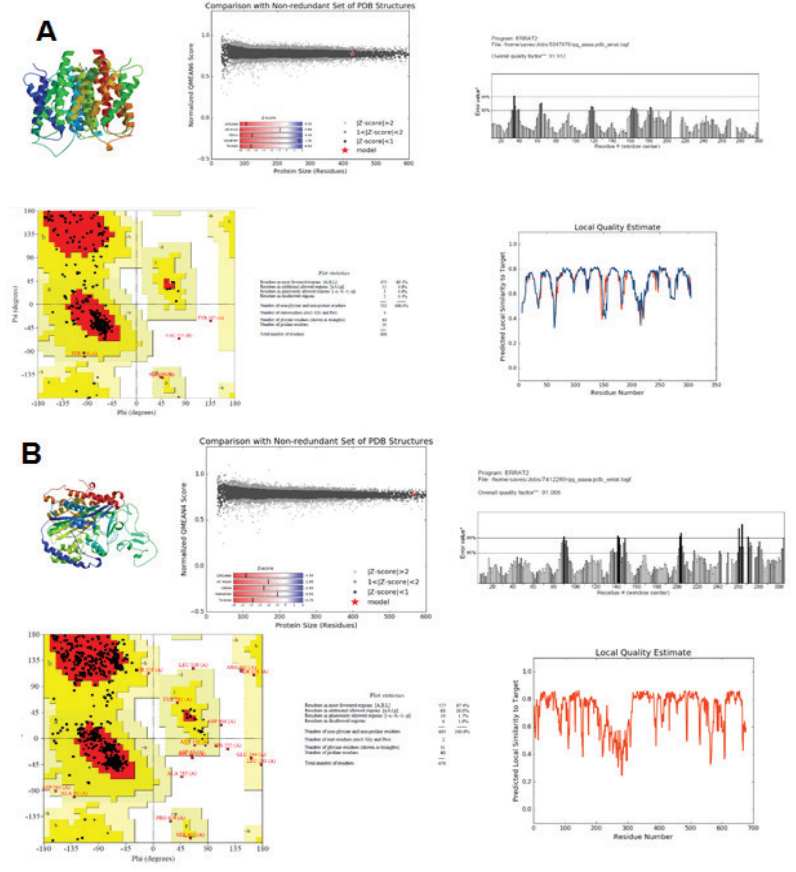

Figure 2. A) The LPG model from L. infantum using homology modeling software, B) The $\gamma$-GCS model from $L$. infantum using homology modeling software. The upper, left figure shows the prepared model for the receptor of interest, the upper, right figure shows model validation with ERRAT, the bottom left figure shows Ramachandran plot with the percentage of amino acids in favored and allowed regions, and the bottom, right figure shows the detail of model local quality 
Model validation was also done and Ramachandran plots were calculated for LPG and $\gamma$-GCS, suggesting $99.1 \%$ vs. $97.4 \%$ residues in the allowed region, respectively. According to ERRAT program results, the total quality factors of provided models for LPG and $\gamma$-GCS were as 91.912 and 91.008, respectively. Chemical properties of selected FDA-approved compounds were given in detail in Table 1.

After the accomplishment of docking on 20000 drug compounds, a total number of seven ligands, two for $\gamma$-GCS receptor and five for LPG receptor, were assigned as novel, potent anti-leishmanial drugs based on their binding affinity and energy (Table 2).

Of these, five ligands possessed cytotoxic and anti-cancer characteristics that showed a good binding capacity to LPG receptor with $\Delta \mathrm{G}_{\text {binding }}$ up to $8.5 \mathrm{kcal} / \mathrm{mol}$ more negative (Figure 2A, C, D, E); while, two compounds showed good binding capacity to Glutamyl receptor with $\Delta G_{\text {binding }}$ up to $7.8 \mathrm{kcal} / \mathrm{mol}$ more negative (Figure $3 \mathrm{~A}$ and $\mathrm{B}$ ) . The selected compound 186 inserted in the hydrophobic pocket created by Met237, Val241, Ser254, and Gly260, as shown in Figure 2A. The compound 427 inserted in the hydrophobic pocket created by Thr104, Lys107, Met237, Thr238, and Val241, as shown in Figure 2B. The compound 446

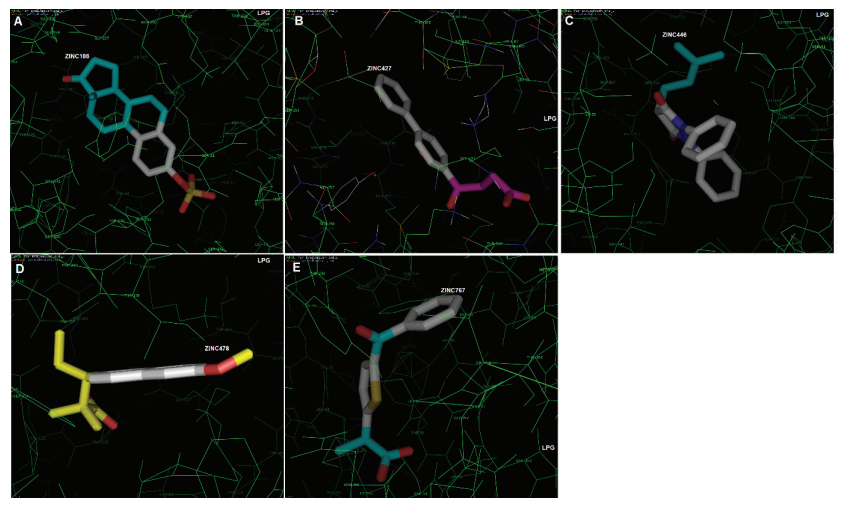

Figure 3. A) Experimental ligand no. 186 (zinc186) that showed H-binding to LPG receptor, B) experimental ligand no. 427 (ZINC427) that showed H-binding to lipophosphoglycan (LPG) receptor C) experimental ligand no.446 (ZINC446) forms H-bond with LPG receptor, D) experimental ligand no.478 (ZINC478) forms H-bonds with LPG receptor, E) Experimental ligand no.767 (ZINC767) that showed H-binding to LPG receptor form L.infantum. The selected compound 183 inserted in the hydrophobic pocket created by Gly321, Val381, Ser474, Gln479, and Arg498, as shown in Figure 3A. The compound 648 inserted in the hydrophobic pocket created by Pro91, Leu189, Glu192, Ser474, and Trp477, as shown in Figure 3B.

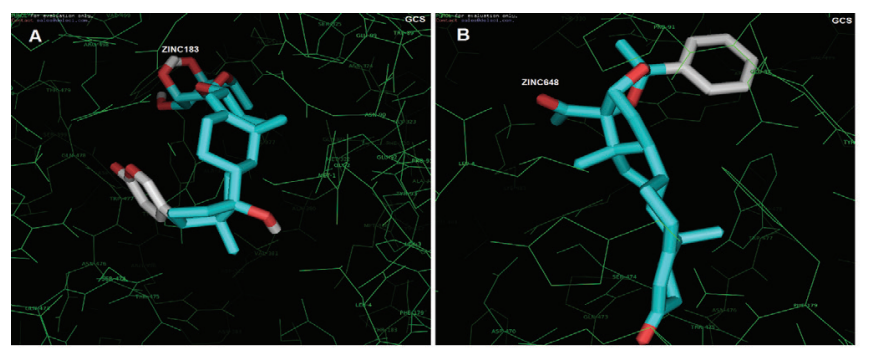

Figure 3. A) Experimental ligand no. 183 (zinc183) that showed H-binding to $\gamma$-GCS receptor, B) experimental ligand no. 648 (ZINC648) that showed H-binding to $\gamma$-GCS receptor form L. infantum

GCS: Glutamylcysteine synthetase

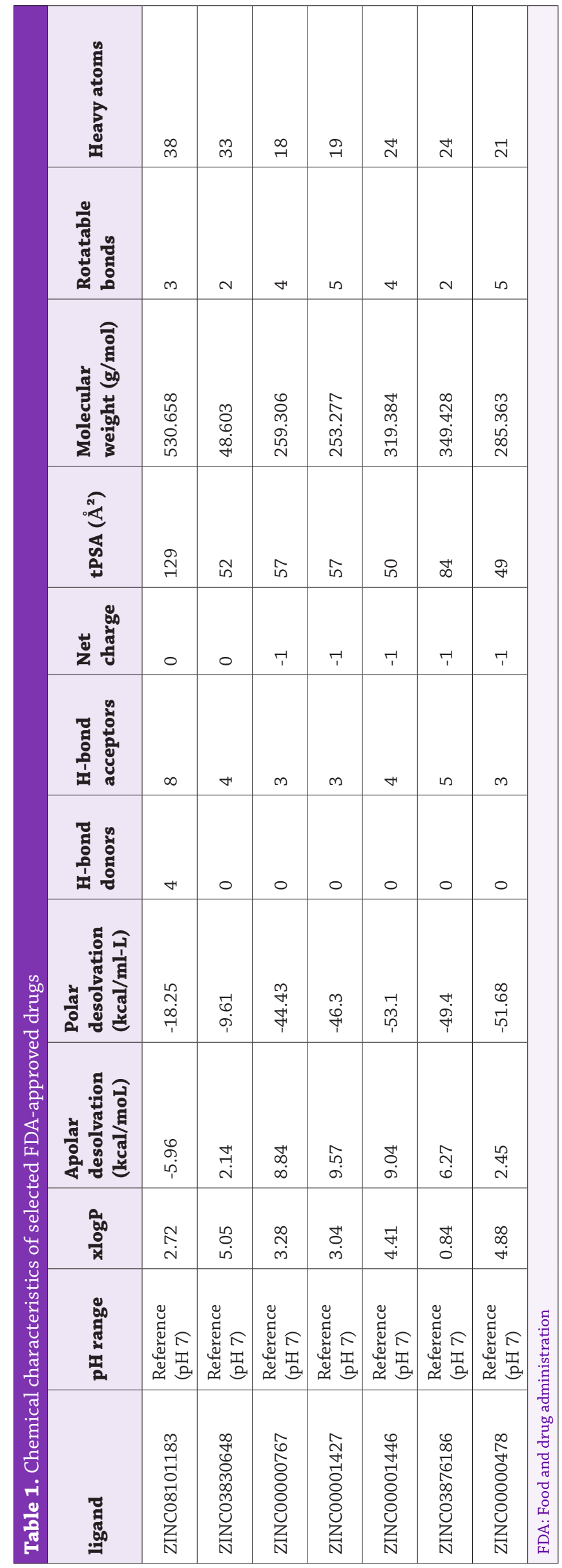




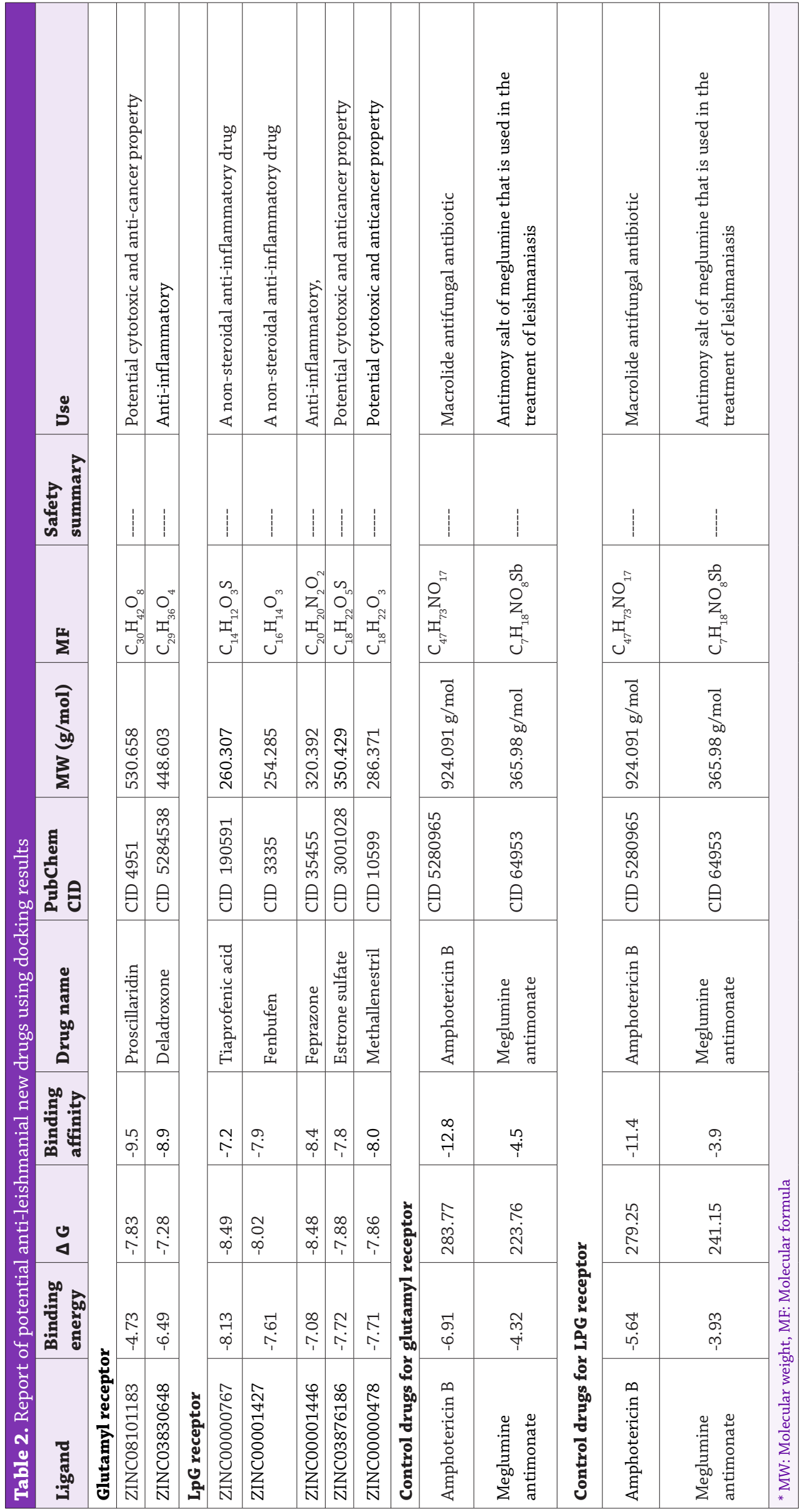

inserted in the hydrophobic pocket created by Val111, Thr166, Tyr169, Met253, and Gly257, as shown in Figure 2C. The compound 478 inserted in the hydrophobic pocket created by Thr104, Lys107, Ala110, Ser254, and Gly257, as shown in Figure 2D. The compound 767 inserted in the hydrophobic pocket created by Thr48, Leu82, Met92, Leu195, and Asn260, as shown in Figure 2E.

\section{DISCUSSION}

The routine medications used against VL usually entail cytotoxicity, discomfort, and development of resistant strains (7,24-26). Hence, peptides with various metabolic activity may be considered as potent vaccine candidates and drug targets $(27,28)$. During the invasion, Leishmania expresses a wide spectrum of proteins with different metabolic and/or pathogenic activity $(29,30)$. A number of such proteins have been discerned as drug targets for modern leishmaniasis treatment, including dihydrofolate reductase, pteridine reductase enzymes, protein kinases and topoisomerases $(6,31,32)$. With respect to the function of $\gamma$-GCS and LPG in immune evasion and parasite survival $(15,18)$, we selected them as robust drug targets in our investigation, which hadn't been assessed previously. As the most plentiful GPI-anchored molecule of Leishmania promastigotes, LPG has been proved to be central to complement inhibition, macrophage entrance, transformation to amastigote form and tolerance to hydrolytic and oxidant circumstances (33). The thiol redox metabolism is one of the outstanding genetic hallmarks of Leishmania (34). Trypanothione $\left[\begin{array}{lll}\mathrm{T} & (\mathrm{SH})_{2}\end{array}\right]$ system constitutes a considerable part of reduced thiols, which equips the parasite to withstand drugs with antimonial elements (35-37). The first step of $\mathrm{T}(\mathrm{SH})_{2}$ biosynthesis is catalyzed by $\gamma$-GCS enzyme, which has also been identified in an evolutionaryrelated organism, Trypanosoma brucei (T. Brucei) (34,38). Wild resistant isolates (39) or cultivated Leishmania parasites (40) have been shown to overexpress or amplify the $\gamma-G C S$ gene. Furthermore, RNAi knock-down of the respective gene resulted in cell death of T. brucei (41). These findings 
highlight the significance of $\gamma$-GCS, the important rate-limiting catalyzer of glutathione biosynthesis, as a compelling drug target for modern leishmaniasis treatment options.

The "in-silico" analysis which stands for computer-based biological experiments, is a state-of-the-art and accurate method to discover exclusive bioactive compounds, which may represent novel metabolic pathways and/or a powerful affinity to a certain target (42). In this sense, several studies have identified unprecedented molecules for various drug targets in Leishmania, such as pteridine reductase1, tryparedoxin peroxidase and sterol biosynthesis (43-48), as well as in other single-celled eukaryotes enclosing Toxoplasma gondii, Cryptosporidium hominis, Plasmodium and Trypanosoma cruzi (49-51). Current in-silico investigation was aimed to screen and predict the anti-leishmanial potency of 3358 FDA-approved compounds against both drug targets in $L$. infantum in comparison to amphotericin B and glucantime for the discovery of new biochemical molecules. Using computer-aided tools, only seven out of 3358 tested compounds were qualified to be a biological ligand for our targets, three with anti-tumor activity and the others with anti-inflammatory features. Approving the antiprotozoal activity of certain compounds with anti-cancer or anti-inflammatory properties is one of the significant advances. The putative cytotoxicity induced by anti-cancer compounds in Leishmania may arise from the truth that both tumor cells and parasites assign biochemical analogies, which impact DNA and polyamine metabolism, glucose catabolism and the pathways of protein kinases (52). Similar to apoptosis pathway of multicellular livings, a fascinating mechanism of programmed cell death has also been recognized in protists such as Leishmania spp., which could be a rational explanation for outlandish anti-leishmanial effects of some antitumor substrates $(53,54)$. So far, a number of anticancer drugs with various mechanisms of action have been tested for the aim of leishmaniasis treatment in vitro and in vivo, including doxorubicin (interaction with DNA), anilineacrydines (topoisomerase II inhibition), phospholipid analogues (lipid metabolism inhibition and cell membrane destruction), 8-hydroxyquinolines (inhibition of electron transfer chain) and sunitinib (tyrosine kinase inhibitor) (32). Among these, tamoxifen, raloxifene, imiquimod, imatinib and sunitinib possessed good results in leishmaniasis animal models and are appropriate candidates for further evaluations (32). The efficacy of some anticancer protein kinase inhibitors was evaluated by Sanderson et al. (55), showing sarafenib, lapatinib and sunitinib as bioactive compounds against $L$. donovani amastigotes in murine macrophages. In the context of anti-leishmanial activity of antiinflammatory drugs, few compounds have been examined and less is understood regarding how they would impress the parasite molecular targets. For instance, murine systematic leishmaniasis was shown to be inhibited by acetyl salicylic acid-induced nitric oxide immunomodulation (56); however, this finding doesn't indicate a ligand-target interplay. Thus, the impact of antiinflammatory drugs on potent Leishmania drug targets requires further in-silico and in vitro excavation and is still open to question.

In total, high-throughput computer-aided analyses showed us a number of anti-inflammatory and anti-cancer compounds with anti-leishmanial activity, according to their well-established interaction to the respective parasite ligands ( $\gamma$-GCS and LPG). However awaits in vitro, in vivo and clinical validations, such repurposed compounds would inhibit the parasite survival more efficiently than control drugs, as confirmed by in-silico investigations and obviates the need for current costly drugs with significant side effects.

\section{CONCLUSION}

With the advent of the computer era, software-based tools have paid a huge contribution in accurate predictions, comprising epitope mapping, drug-target interactions, etc. This cutting-edge method helps us to screen and predict novel peptide templates specific to biological targets in organisms leading to novel drug discovery. The present study demonstrated seven potent antileishmanial ligands out of 20000 FDA-approved explored compounds exist for LPG and $\gamma$-GCS drug targets. Although, in vitro and in vivo confirmations are also an inevitable requisite for further assessment of the potentiality of the predicted ligands. With the help of in-silico approaches identifying the molecular mechanism of action of the more active compounds was possible; thus, could define the most likely molecular target, so that the subsequent optimization using in vitro and in vivo techniques can be undertaken.

\section{* Ethics}

Ethics Committee Approval: Ethics committee approval name and number are respectively IR.AJUMS.REC and 1396614.

Informed Consent: A consent form was completed by all participants.

Peer-review: Internally peer-reviewed.

\section{* Authorship Contributions}

Concept: F.R., F.S., J.S., R.A., Design: F.R., F.S., J.S., R.A., Data Collection or Processing: F.R., F.S., J.S., R.A., Analysis or Interpretation: F.R., F.S., J.S., R.A., Literature Search: F.R., F.S., J.S., R.A., Writing: F.R., F.S., J.S., R.A.

Conflict of Interest: No conflict of interest was declared by the authors.

Financial Disclosure: The authors declared that this study received no financial support.

\section{REFERENCES}

1. Kevric I, Cappel MA, Keeling JH. New world and old world Leishmania infections: a practical review. Dermatol Clin 2015;33:579-93.

2. Postigo JAR. Leishmaniasis in the world health organization eastern mediterranean region. Int J Antimicrob Agents 2010;36 Suppl 1:S62-5.

3. Leishmaniasis W. WHO, Fact Sheet No. 375. WHO: Geneva, Switzerland. 2015.

4. Alvar J, Velez ID, Bern C, Herrero M, Desjeux P, Cano J, et al. Leishmaniasis worldwide and global estimates of its incidence. PloS One 2012;7:e35671.

5. Dujardin JC. Risk factors in the spread of leishmaniases: towards integrated monitoring? Trends Parasitol 2006;22:4-6.

6. Khademvatan S, Adibpour N, Eskandari A, Rezaee S, Hashemitabar M, Rahim F. In silico and in vitro comparative activity of novel experimental derivatives against Leishmania major and Leishmania infantum promastigotes. Exp Parasitol 2013;135:208-16.

7. Chakravarty J, Sundar S. Drug resistance in leishmaniasis. J Glob Infect Dis 2010;2:167-76.

8. Thakur C, Sinha G, Pandey A, Kumar N, Kumar P, Hassan S, et al. Do the diminishing efficacy and increasing toxicity of sodium stibogluconate in the treatment of visceral leishmaniasis in Bihar, India, justify its continued use as a first-line drug?Ann Trop Med Parasitol 1998;92:561-9.

9. Ma D-L, Chan DS-H, Leung C-H. Drug repositioning by structure-based virtual screening. Chem Soc Rev 2013;42:2130-41.

10. Drews J. Drug discovery: a historical perspective. Science 2000;287:1960-4.

11. Rahim F. An in silico development of selective inhibitor for histamine receptors. Biotechnology 2010;9:157-63.

12. Adibpour N, Rahim F, Rezaeei S, Khalaj A, Ebrahimi A. In silico designing selective inhibitor of drugs, medicinal plants compounds and experimental 
ligands for pteridine reductase targeting visceral leishmaniasis. Afr J Microbiol Res 2012;6:917-26.

13. Castro H, Tomás AM. Peroxidases of trypanosomatids. Antioxidants \& redox signaling. 2008;10(9):1593-606.

14. Flohe L, Hecht H, Steinert P. Glutathione and trypanothione in parasitic hydroperoxide metabolism. Free Radic Biol Med 1999;27:966-84.

15. Griffith OW. Biologic and pharmacologic regulation of mammalian glutathione synthesis. Free Radic Biol Med 1999;27:922-35.

16. Orlowski M, Meister A. Partial reactions catalyzed by $\gamma$-glutamylcysteine synthetase and evidence for an activated glutamate intermediate. J Biol Chem 1971;246:7095-105.

17. Forestier C-L, Gao Q, Boons G-J. Leishmania lipophosphoglycan: how to establish structure-activity relationships for this highly complex and multifunctional glycoconjugate? Front Cell Infect Microbiol 2015;4:193.

18. Lima JB, Araújo-Santos T, Lázaro-Souza M, Carneiro AB, Ibraim IC, Jesus-Santos FH, et al. Leishmania infantum lipophosphoglycan inducedProstaglandin E 2 production in association with PPAR- $\gamma$ expression via activation of Toll like receptors-1 and 2. Scientific Reports 2017;7:14321.

19. Van Der Spoel D, Lindahl E, Hess B, Groenhof G, Mark AE, Berendsen HJ. GROMACS: fast, flexible, and free. J Comput Chem 2005;26:1701-18.

20. Zarezade V, Abolghasemi M, Rahim F, Veisi A, Behbahani M. In silico assessment of new progesterone receptor inhibitors using molecular dynamics: a new insight into breast cancer treatment. J Mol Model 2018;24:337.

21. Li Q, Shah S. Structure-Based Virtual Screening. Methods Mol Biol 2017;1558:111-24

22. Trott O, Olson AJ. AutoDock Vina: improving the speed and accuracy of docking with a new scoring function, efficient optimization, and multithreading. J Comput Chem 2010;31:455-61

23. Romero GA, Boelaert M. Control of visceral leishmaniasis in Latin America—a systematic review. PLoS Negl Trop Dis 2010;4:e584.

24. Croft SL, Sundar S, Fairlamb AH. Drug resistance in leishmaniasis. Clin Microbiol Rev 2006;19:111-26.

25. Singh N, Kumar M, Singh RK. Leishmaniasis: current status of available drugs and new potential drug targets. Asian Pac J Trop Med 2012;5:48597.

26. Tiuman TS, Santos AO, Ueda-Nakamura T, Dias Filho BP, Nakamura CV. Recent advances in leishmaniasis treatment. Int $\mathrm{J}$ Infect Dis 2011;15:e525-e32.

27. Davis AJ, Kedzierski L. Recent advances in antileishmanial drug development. Curr Opin Investig Drugs 2005;6:163-9.

28. Kedzierski L, Sakthianandeswaren A, Curtis JM, Andrews PC, Junk PC, Kedzierska K. Leishmaniasis: current treatment and prospects for new drugs and vaccines. Curr Med Chem 2009;16:599-614.

29. Sibley L. Intracellular parasite invasion strategies. Science 2004;304:24853.

30. Vannier-Santos M, Martiny A, Souza WD. Cell biology of Leishmania spp.: invading and evading. Curr Pharm Des 2002;8:297-318.

31. Gilbert IH. Inhibitors of dihydrofolate reductase in Leishmania and trypanosomes. Biochim Biophys Acta 2002;1587:249-57.

32. Keighobadi M, Akhtari J, Fakhar M, Emami S, Mirzaei H. An Overview on Anticancer Drugs with Antileishmanial Activity. J Mazandaran Univ Med Sci 2018;28:154-65.

33. Späth GF, Garraway L, Turco SJ, Beverley SM. The role (s) of lipophosphoglycan (LPG) in the establishment of Leishmania major infections in mammalian hosts. Proc Natl Acad Sci U S A 2003;100:953641.

34. Mukherjee A, Roy G, Guimond C, Ouellette M. The $\gamma$-glutamylcysteine synthetase gene of Leishmania is essential and involved in response to oxidants. Mol Microbiol 2009;74:914-27.

35. Mandal G, Wyllie S, Singh N, Sundar S, Fairlamb A, Chatterjee M. Increased levels of thiols protect antimony unresponsive Leishmania donovani field isolates against reactive oxygen species generated by trivalent antimony. Parasitology 2007;134:1679-87.

36. Mittal MK, Rai S, Ashutosh, Ravinder, Gupta S, Sundar S, et al. Characterization of natural antimony resistance in Leishmania donovani isolates. Am J Trop Med Hyg 2007;76:681-8.
37. Wyllie S, Vickers TJ, Fairlamb AH. Roles of trypanothione S-transferase and tryparedoxin peroxidase in resistance to antimonials. Antimicrob Agents Chemother 2008;52:1359-65.

38. Abbott JJ, Ford JL, Phillips MA. Substrate binding determinants of Trypanosoma brucei $\gamma$-glutamylcysteine synthetase. Biochemistry 2002;41:2741-50

39. Mukherjee A, Padmanabhan PK, Singh S, Roy G, Girard I, Chatterjee $\mathrm{M}$, et al. Role of $\mathrm{ABC}$ transporter MRPA, $\boldsymbol{\gamma}$-glutamylcysteine synthetase and ornithine decarboxylase in natural antimony-resistant isolates of Leishmania donovani. J Antimicrob Chemother 2007;59:204-11.

40. Haimeur A, Brochu C, Genest P-A, Papadopoulou B, Ouellette M. Amplification of the $\mathrm{ABC}$ transporter gene PGPA and increased trypanothione levels in potassium antimonyl tartrate (SbIII) resistant Leishmania tarentolae. Mol Biochem Parasitol 2000;108:131-5.

41. Huynh TT, Huynh VT, Harmon MA, Phillips MA. Gene knockdown of $\gamma$-glutamylcysteine synthetase by RNAi in the parasitic protozoa Trypanosoma brucei demonstrates that it is an essential enzyme. J Biol Chem 2003;278:39794-800.

42. Saeidnia S, Manayi A, Abdollahi M. The pros and cons of the in-silico pharmaco-toxicology in drug discovery and development. Int J Pharm 2013;9:176-81.

43. Ferrari S, Morandi F, Motiejunas D, Nerini E, Henrich S, Luciani R, et al. Virtual screening identification of nonfolate compounds, including a CNS drug, as antiparasitic agents inhibiting pteridine reductase. J Med Chem 2011;54:211-21.

44. Gundampati RK, Sahu S, Srivastava AK, Chandrasekaran S, Vuddanda PR, Pandey RK, et al. In silico and in vitro studies: tryparedoxin peroxidase inhibitor activity of methotrexate for antileishmanial activity. Am J Infect Dis 2013;9:117.

45. Herrmann FC, Sivakumar N, Jose J, Costi MP, Pozzi C, Schmidt TJ. In Silico Identification and In Vitro Evaluation of Natural Inhibitors of Leishmania major Pteridine Reductase I. Molecules 2017;22:2166.

46. Kaur J, Kumar P, Tyagi S, Pathak R, Batra S, Singh P, et al. In silico screening, structure-activity relationship, and biologic evaluation of selective pteridine reductase inhibitors targeting visceral leishmaniasis. Antimicrob Agents Chemother 2011;55:659-66.

47. Scotti L, Ishiki H, Mendonca F, Da Silva M, Scotti M. In-silico analyses of natural products on leishmania enzyme targets. Mini Rev Med Chem 2015;15:253-69.

48. Croft SL, Coombs GH. Leishmaniasis-current chemotherapy and recent advances in the search for novel drugs. Trends Parasitol 2003;19:502-8.

49. Dasgupta T, Chitnumsub P, Kamchonwongpaisan S, Maneeruttanarungroj C, Nichols SE, Lyons TM, et al. Exploiting structural analysis, in silico screening, and serendipity to identify novel inhibitors of drug-resistant falciparum malaria. ACS Chem Biol 2009;4:29-40.

50. Pelphrey PM, Popov VM, Joska TM, Beierlein JM, Bolstad ES, Fillingham YA, et al. Highly efficient ligands for dihydrofolate reductase from Cryptosporidium hominis and Toxoplasma gondii inspired by structural analysis. J Med Chem 2007;50:940-50.

51. Santos CC, Lionel JR, Peres RB, Batista MM, da Silva PB, de Oliveira GM, et al. In vitro, in silico and in vivo analysis of novel aromatic amidines against Trypanosoma cruzi. Antimicrob Agents Chemother 2017:AAC02205-17.

52. Perez JM, Fuertes MA, Nguewa PA, Castilla J, Alonso C. Anticancer compounds as leishmanicidal drugs: challenges in chemotherapy and future perspectives. Curr Med Chem 2008;15:433-9.

53. Deponte M. Programmed cell death in protists. Biochim Biophys Acta 2008;1783:1396-405.

54. Lee N, Bertholet S, Debrabant A, Muller J, Duncan R, Nakhasi H. Programmed cell death in the unicellular protozoan parasite Leishmania. Cell Death Differ 2002;9:53-64.

55. Sanderson L, Yardley V, Croft SL. Activity of anti-cancer protein kinase inhibitors against Leishmania spp. J Antimicrob Chemother 2014;69:1888-91.

56. Nahrevanian H, Jalalian M, Farahmand M, Assmar M, Rastaghi AE, Sayyah M. Inhibition of murine systemic leishmaniasis by acetyl salicylic acid via nitric oxide immunomodulation. Iran J Parasitol 2012;7:21-8. 